\title{
Soes for Female Artist Divorce in the Study of Economy Political Media
}

\author{
Laksmi Rachmaria \\ laksmi.rachmaria@budiluhur.ac.id \\ Universitas Budi Luhur
}

\begin{abstract}
This study aims to dismantle the ideology and interests that have been frozen in the language behind the divorce of the artist Julia Perez on the Seleb On News program, MNC TV. This study uses a qualitative approach with Norman Fairclough's Critical Discourse Analysis method with three dimensions which are the main focus points, namely texts, discursive practices and social praxis. The results of the study: through the text of the editorial news Seleb On News MNC TV has made the issue of women a commodity. Artist Julia Perez's divorce suit was told dramatically and moving. Seleb On News sells the sadness and tears of women for their business interests while preserving the ideology of patriarchy by portraying a woman as a weak creature. Conclusion: journalists have full power over the choice of words and facts that they will use when constructing an event. There are prices in the news. The interests of media organizations cannot be avoided when constructing a reality. Seleb On News carries out several actions that ultimately provide benefits to media companies / organizations.
\end{abstract}

Keywords: language, commodities, news

\section{Introduction}

Media is a mirror of social reality. However, the reality displayed by the media is not always true. On the one hand, the media reflects the circumstances around it, but on the other hand it also shapes reality itself through its selective attitude in choosing the things it wants to express, including the way the media presents them. Here the media provides interpretations, such as the strengthening of values, attitudes, and patterns of community behavior.

The media can choose which reality to display and hide the reality they want. The choice of certain words used by the media is not just part of journalistic techniques, but rather in language politics. All aspects used to make certain dimensions of a news construction become more meaningful and remembered by the public, so that understanding and construction of the same event may be different between one media and another.

Celebrity personal life is an event that often gets attention from the mass media, whether it's about news of marriage, divorce, birth or death of these public figure figures. Julia Perez is one of the many female artists who sued for divorce her husband. In 2015 there were 16 celebrity divorce cases. Of the 16 cases, 14 were divorced cases where the plaintiffs were women (wives) [1]

The case of divorce Jupe has its own charm. Jupe called the day of divorce a "day of independence", She also did some special preparations for all purple colors ranging from wigs, clothes to shoes, where purple was a symbol of a widow. In the case of Jupe's divorce, the community also learned about several articles contained in the Law on the Elimination of Domestic Violence.

When a news editor produces a story, he conducts a selection process and selects which messages will be delivered to the audience. In this selection process the background and 
interests of individuals and the interests of media organizations cannot be avoided in constructing reality. They often carry out various actions that ultimately give benefits to companies / media organizations. For them, the first information market (news business) is to make a profit [2], should not be late, may not be preceded by other media or television stations, not to get the rating down and so forth. In this case, media coverage and all company activities are measured by how much sales value can be generated from a news story.

There are prices in the news [3]. The use of real language is not transparent, in the sense that a discourse is written in a news text loaded with rhetoric, manipulation and misdirection. In this case the discourse does not directly reveal the sincere intentions of the news writer.

Although journalists, both print and electronic, are reluctant to admit that news is a commodity traded on the market. From reporters to executives, executives prefer to call themselves civil servants rather than as information traders [4]. The editor exchanges the information needed to the public. People buy it with attention, they watch news programs. Community attention is then sold by media companies to advertisers. From advertisers, new media get money. Advertisers contribute around $70 \%-90 \%$ of gross revenue from news programs.

Regarding media political economy Vincent Mosco then proposed 3 (three) entry point concepts for the application of the political economy theory of the media in the communications industry, namely commodification, spatialization and structuration [5]. commodification refers to the use of goods and services that can be seen from their usefulness which are then transformed into a commodity where the value is determined by the market. The commodification form in communication basically has 3 (three) types, namely intrinsic commodification (content), extrinsic commodification and commodification of cybernetics. How journalists use their ability to professionally package news, load opinion articles, advertisements, or write an author in a package that can be sold is an example of intrinsic commodification. Seleb on News MNC TV is an infotainment program that falls into the top 5 highest rating. Unlike the infotainment program in general, the Seleb On News infotainment program is MNC TV's in house production under the Department of News or MNC News, so it is expected to prioritize journalistic rules when reporting on an event.

\section{Methodology}

This study used a qualitative approach with Norman Fairclogh's Critical Discourse Analysis method. Critical Discourse Analysis tries to uncover something that is wrong or wrong in the community, such as injustice, inequality, limitation of freedom or discrimination [6] in this case the author wants to dismantle commodification practices in the political economy perspective of the media contained in the lawsuit divorce artist Julia Perez. Fairclough told there are a three-dimensional method of discourse analysis. Discourse, and any specific instance of discursive practice, is seen as simultaneously (i) a language text, spoken or written, (ii) discourse practice (text production and text interpretation), (iii) sociocultural practice [7]

\section{Result}

\subsection{Text Analysis}

To analyze the text, researchers used Robert N. Entman's framing analysis technique. Framing is a method of presenting reality in which truth is not totally denied, but rather "deflected" subtly by giving prominence to certain aspects. The aspects that were hidden by the media then became forgotten and not even considered by the public at all.

\section{Frame of MNC TV's Celebrity On News}


Define the Problem, Seleb On News defines Jupe's case for divorce over Gaston Castano into the realm of law. Everything from the news about Jupe's divorce lawsuit to her husband Gaston Castano was highlighted in terms of the Law. Diagnose Causes, in the whole text of the news on the news of Seleb On News, defining the cause of the problem in this case is Gaston Castano, husband of artist Julia Perez. Gaston is portrayed as a play boy and materialistic male figure who uses Julia Perez. This can be seen in the following text and images:

\begin{tabular}{|l|l|l|}
\hline No. & News Text & EXCEPT rumored to double Jupe / \\
GASTON ALSO AS ALLEGED USE \\
ONLY GUY Matre Jupe / LUXURY CAR \\
FROM THE FANTASTIC VALUE \\
PROVIDED AS A BIRTHDAY GIFT Jupe \\
GASTON / FOR THEM TO THE COST \\
OF LIVING THROUGH WHEN // \\
COurting process GASTON INJURY AND \\
CAN NOT EXPERIENCE PLAYING \\
SOCCER / JUPE LAH WHO CURRENT \\
THE NEED OF LIVING GASTON (Diary \\
Of Love Jupe-Gaston.) On News March 16, \\
2016)
\end{tabular}

Table 1 News Text

The fact is Seleb on News uses words as well as sentences to reinforce the news frame, like the word "dub" that describes Gaston as an unfaithful man, betrayed at marriage, torturing Jupe from his psychological side. The phrase " Matreliasitist ", "Jupe only," "Fantastic Luxury Car", "Jupe is the one who finances Gaston's life needs" is a description of the domestic forms of violence that Gaston has done to his wife: violence in the economy, economically exploit Julia Perez also abandoned her livelihood which should be her responsibility as a husband. Further Seleb On News also featured Gaston's facts as a husband who had abandoned his livelihood by quoting Jupe's statement. "During this time Gaston boasted that in his country he, that he had no obligation to support me, he was wrong. In Indonesia is not like that, let alone he knows the law in Indonesia like what. Now he understands that the law in Indonesia respects the rights of women and he now has to pay, it is required 15 Million per month ". Seleb On News helped to strengthen patriarchal ideology, namely to describe women (Jupe) as a weak figure and to sell women's suffering and tears.

In addition to using words, Seleb on News sentences and images also use music illustrations in the form of pieces of songs I Want to Break free which were sung again by the band Dewa. The contents of the song lyrics describe a condition or situation where a person has been freed from a great burden. News writers want to link the conditions experienced by Jupe as illustrated in the lyrics of the song. News writers want to show that divorce or a woman who sues for divorce is not always negative, women have the right to fight for happiness especially when in her married life she experiences domestic violence. Jupe is 
described as a strong figure, who dares to "fight" the culture or values that have been in society. Jupe preferred to be a widow instead of living in marriage. Make Moral Judgment. Seleb on News contains a moral claim that happiness is the right of every human being who must be fought for a Recommendation Treatment. Based on the background of defining the problem, determining the cause of the problem or the victim as well as the moral claims presented, Seleb on News provides a solution to the problem in the form of Jupe entitled to Happy, Gaston deserves to be divorced. The use of words, illustrations of music or images are forms of intrinsic commodification carried out by Seleb On News, MNC TV.

\subsection{Discursive Practice}

Journalists live in media institutions with a set of rules, work patterns, habits, rules, norms, ethics and routines themselves. MNC TV is a commercial television station that lives in the midst of intense competition in the television industry. Infotainment is one of the leading programs for commercial television stations. The events surrounding the lives of artists become "fine dining" for infotainment journalists.

"Like another infotainment, Seleb On News also conducts editorial meetings, projections meetings. We are meeting first tomorrow, what will we play (what is the news, red), we will raise the case, Jupe, because at that time the trial was indeed going on ... and that attracted a lot of attention from viewers. [8]. The higher the news value an event has, the higher its selling value, which ultimately ends up with a high rating rating. Julia Perez's lawsuit against her husband contained the news value of conflict, human interest, excellence, impact, (at that time), therefore it is not surprising that television stations competed to be able to broadcast the latest information about Julia Perez's divorce case. Seleb On News also made efforts not to lose in the competition, among others by holding reports directly from the location of the trial with the aim of other than the speed factor also for reasons of distinctiveness, which distinguishes programs from other infotainment. This is more about other infotainments, because maybe other infotainments will discuss Jupe only at the core of the event, but if we are present, as if the viewers were presented directly from the scene "[8].

Seleb On News also uses internet technology to strengthen its position in the midst of competition. We want to grab fans of Jupe. Young mothers are 20-40 years old. On Instagram there is a name jupelicius, followers of Jupe. Jupe is their idol, they want to know the information about their idols, they want their idols to be fully supported. So when the news will air, we tag all of Jupe's followers to watch. We go to their Instagram, and we also have our own IG celebrity on news.mnctv. now because the era is socialized, we must also participate in it. We have IG, there is FB, twitter. We have a social media team. Before the program aired, I had to send a streaming video on Twitter for the promo, then blast it to those who aired that day" [8]

\subsection{Cultural Practise}

Iswanti, as the producer of the Seleb On News Program, as a woman she wants to defend her people. He tried to struggle in the news text she produced, such as trying to portray Jupe's figure as a strong female figure, who broke down the negative stigma about women who sued for divorce. However, Iswanti is part of MNC TV, where the media world is currently patriarchal [9], because the people involved in the world of media are dominated by men. More broadly, She, Iswanti is also in the global patriarchal system. Patriarchate is an asymmetrical relationship between men and women which places men more dominant than women.

The mass media has the power and big role in shaping reality. the reality created by the media is symbolic reality which is the product or engineering of the managers (editors, 
journalists, producers, and all the people who work in it. They choose the reality that they want to display while also hiding the reality that is not supporting the construction of the news.

In addition to patriarchal ideology, competition with other TV stations, Seleb On News will do various ways to attract the attention of viewers. The audience's attention is then recorded in the rating data sold to advertisers. Seleb On News also uses social media to increase its program rating.

"So when the news will air, we tag all of Jupe's followers to watch. We go to their Instagram, and we also have our own IG celebrity on news.mnctv. now because the era is socialized, we must also participate in it. We have IG, there is FB, twitter. We have a social media team. Before the program aired, I had to send a streaming video on Twitter for the promo, then blast it to those who aired that day" [8].

Borrowing terms T. Titi Widianingsih patriarchal system puts the media in this case Seleb On News in a condition of blessing in disgues for media companies in building their business. In the midst of a highly patriarchal media community (Seleb On News) sacrificing women in the news text and selling women's sadness and tears.

\section{Conclusion}

Mass media including in this case television basically does not reproduce reality, but determines (to define) existing reality through the use of words, sentences or images. Each word used in a media text shows an ideological practice.As part of mass media, the news editor of the Seleb on News MNC TV is in two big pressures; economic pressure and patriarchal culture. Through the news text, the editor of Seleb on News has made the issue of women a commodity.

Our mental structure interlinks with ideology through language. Language is not a neutral communication tool but it is liquid, ambiguous, because through certain ideological languages we program it without us knowing it.

\section{References}

[1] M. TV, “Kaledoskop Seleb On News 31 Desember 2015,” 2015.

[2] Haryatmoko, Etika Komunikasi. Yogyakarta: Kanisius, 2007.

[3] G. Burton, Discusses an introductory television to television studies. Jalasutra Yogyakarta, 2007.

[4] J. H. McManus, Market-Driven Journalism. Sage Publications, 1994.

[5] Vincent Mosco, The Political Economy of Communication. London: SAGE Publications, 1996.

[6] Haryatmoko, Critical Discourse Analysis (Analisis Wacana Kritis) Landasan Teori, Metodologi dan Penerapan. Yogyakarta: Kanisius, 2016.

[7] N. Fairclough, Critical Discourse analysis the critical study of language, Second. Pearson Education Limited, 2010.

[8] L. Rachmaria, "Interview Seleb On News Producer," 2017.

[9] T. T. Widianingsih, "Konstruksi Realitas Perempuan dalam Berita Harian Kompas," Komunitas, vol. 1, no. Juli, pp. 24-50, 2011. 